\title{
UNIVERSITYOF
}

FORWARD

THINKING

WESTMINSTER用

WestminsterResearch

http://www.westminster.ac.uk/westminsterresearch

Gamification and Entrepreneurial Intentions

Ruiz-Alba, J., Soares, A., Rodríguez-Molina, M. and Banoun, A.

This article is (C) Emerald and permission has been granted for this version to appear here: http://westminsterresearch.westminster.ac.uk/

Emerald does not grant permission for this article to be further copied/distributed or hosted elsewhere without the express permission from Emerald Group Publishing Limited.

The final, published version in Journal of Small Business and Enterprise Development, DOI: $10.1108 / J S B E D-09-2018-02662018$ is available at:

https://dx.doi.org/10.1108/JSBED-09-2018-0266

The WestminsterResearch online digital archive at the University of Westminster aims to make the research output of the University available to a wider audience. Copyright and Moral Rights remain with the authors and/or copyright owners.

Whilst further distribution of specific materials from within this archive is forbidden, you may freely distribute the URL of WestminsterResearch: ((http://westminsterresearch.wmin.ac.uk/)).

In case of abuse or copyright appearing without permission e-mail repository@westminster.ac.uk 


\title{
Gamification and Entrepreneurial Intentions
}

\begin{abstract}
Purpose - This paper investigates how gamification can influence entrepreneurial intentions (EI) of a group of users of an online platform provided by a private company.
\end{abstract}

Design/Methodology/Approach - A quantitative research strategy was used with a sample of 220 respondents. These respondents were tested before and after the gamification experience.

Findings - Main findings support literature suggesting a clear effect of attitudes towards behaviour (ATT) and perceived behavioural control (PBC) on EI, in line with the theory of planned behaviour (TPB). Once the basic assumptions of TPB were confirmed, the authors tested the effects of gamification comparing before and after results. Main findings highlight an increase of these effects after the gamification experience, aligned with the selfdetermination theory.

Practical implications - These findings suggest that gamification is able to influence entrepreneurial behaviours. This contributes to both companies and educators' knowledge on training for EI with gamification and the use of online platforms to this effect. Recommendations are provided.

Originality/value - This is the first study that investigates the impact of Gamification on EI and how Gamification can influence the different relationships between the antecedents of EI.

Keywords - Gamification; Entrepreneurial Intentions (EI); Theory of Planned Behaviour (TBP); Self-Determination Theory (SDT).

Paper type - Research paper 


\section{Gamification and Entrepreneurial Intentions}

\section{Introduction}

Gamification and entrepreneurial intentions (EI) are two relevant topics in the business literature that still lack empirical investigation. These areas have been mostly addressed separately mainly from an organisational/service marketing perspective (Huotari and Hamari, 2017; Vesa et al., 2017) or from an educational perspective (Mwasalwiba, 2010; Liñán, Urbano and Guerrero, 2011). In this study we bridge both fields by investigating how gamification can influence the EI of a group of students of an online platform provided by a privately-owned company and we explore the rationale for investing in this type of gamified products and gamification businesses.

Gamification has been studied in a context of entrepreneurship education which has become a serious matter for University administrators (Gielnik et al., 2015; Rauch and Hulsink, 2015) with a clear impact on economic growth and employment (Audretsch, Grilo and Thurik, 2011). But gamification is relevant not only from an educational standpoint. From a business perspective, gamification is relevant and is gaining momentum as an established industry segment with growth estimates of over US\$ 11 billion by 2020 (Markets and Markets, 2016). From the perspective of policy makers around the globe, many public and social institutions are promoting motivation, engagement, and user experience as vital levers for public policy goals in health, education or civic engagement (Nacke and Deterding, 2017) and gamification is filling this niche (Deterding, 2015). From an academic perspective, gamification is a relatively recent term that became popular with Deterding et al.' $s$ (2011) definition of gamification as the use of game design elements in non-game contexts. Nacke and Deterding (2017) stated that as a research field, gamification has risen to significance recently with no sign of slowing growth, rapidly evolving from a novel research topic into a thriving multi-disciplinary field.

As a result, gamification is not only a temporary buzzword, but instead a major trend that future businesses should consider when dealing with their internal and external customers and which can represent new sources of revenue through differentiated business models (Storbacka et al., 2016; Larivière et al., 2017). Private companies (such as the one considered in this investigation) have developed games and gamification activities which are promoted to other businesses and Universities as a means of helping employees, consumers and students effectively experience situations to help them develop certain skills such as team work, organisational procedures and a myriad of organisational best practices (Kristensson, Wästlund and Söderlund, 2017). Both games and gamification are attributed in research similar positive 
outcomes regarding engagement, motivation and satisfaction (Deterding, et al., 2011; Huotari and Hamari, 2012; Hamari, Koivisto and Sarsa, 2014; Seaborn and Fels, 2015).

In the gamified settings provided by the considered privately owned business, individuals experience entrepreneurial situations or challenges without actually being in that situation which enables the development of their EI or attitudes. The company considered in this study developed this particular platform aiming at firms that wanted to solve challenges in collaboration with young talented students willing to engage in various projects. Some of the participants are from Universities that are committed to entrepreneurship training, but many others are young professionals that are seeking new development opportunities.

Schools, Universities and start-ups are amongst the larger clients of these companies that develop gamification related products. Rauch and Hulsink (2015) have pointed out that educators are developing alternative teaching formats that include games and simulations. Universities and start-ups have become great adopters of new technologies and as such of gamification tools. This has led to a rise in new companies that develop not only online games, platforms and applications, but also to an array of research sponsored by European funding and other institutions to assess their usability and their success.

Nonetheless, there is limited evidence and research is still scarce regarding the effects of these gamified services on performance, motivation, engagement and the development of desired behaviours (Storbacka, et al.., 2016; Dichev and Dicheva, 2017; Kristensson, Wästlund and Söderlund, 2017). Therefore, partnerships with these providers and development of further research on their outcomes is essential going forward for the managerial and academic communities (Mačiulienè and Skaržauskienè, 2016; Larivière, et al., 2017).

The other area investigated in this research is EI that according to Liñán and Fayolle (2015) is a rapidly evolving field of research. In their bibliometric study they identified more than 400 papers investigating EI in the last 10 years, but there are no references to the use of gamification in relation to EI. And most publications in the EI field still focus on the links between entrepreneurship education and behaviours (Gielnik et al., 2015; Rauch and Hulsink, 2015; Fayolle, Verzat and Wapshott, 2016).

For these reasons, the present study tries to understand two research questions: (1) is there any impact of gamification on EI?, and if this is the case, (2) how is gamification influencing the different relationships between the antecedents of EI? This paper also tries to contribute to companies offering gamification solutions with some suggestions regarding the development and adoption of the gamified experiences and the online platforms to stimulate entrepreneurship. Thus, discussing the effects that might be present in adopting such approaches in 
entrepreneurship training is also explored, contributing to both companies and educators' knowledge on training for EI with gamification.

To achieve this, this paper first provides a brief overview of the gamification and entrepreneurship literature. This is followed by the development of the hypotheses suggested for this study and then a description of the methodology employed. Finally, results are presented and discussed. The paper concludes with limitations, suggestions for future research as well as recommendations to business practitioners.

\section{Gamification}

Gamification has been defined as "the use of game design elements in non-game contexts" (Deterding et al., 2011, p.2). Aligned with this, Robson, et al., (2016, p.411) define it as "the application of game-design principles in order to change behaviours in non-game situations". This definition is similar to the one popularized by Deterding et al. (2011), but instead of motivation they refer to change of behaviour. Robson et al., (2016) investigated how firms gamify traditional approaches to create more appealing experiences that facilitate changes in behaviour through employees and customer's engagement. These authors argued that change is channelled through extrinsic reinforcements and intrinsic rewards. In a similar vein, Barata et al., (2017) suggest that gamification tries to engage users to adopt specific behaviours, which is aligned with typical commercial definitions of gamified products. These definitions suggest the existence of a common process where gamification includes three types of elements or principles such as dynamics, mechanism and emotions (Hunicke, Leblanc and Zubek, 2004). Following this, according to Hamari, et al., (2014), gamification can be summarized into three dimensions including: 1) motivational affordances, 2) psychological outcomes, and 3) behavioural outcomes. Dichev and Dicheva (2017) go further and state that gamification is not just a technology, but also a methodology that enables behavioural changes.

These categorizations of the field also suggest the presence of common characteristics within the implementation of a gamification process. Although formal mandatory components of gamification have not been identified, there are a few that are most commonly used or referenced including: (1) experience points and levels (used for rankings and feedback and progress purposes), (2) challenges or quests (tasks with clear goals and increasing difficulty levels), (3) badges (that are distributed to boost motivation) and (4) leader boards (that stimulate competitiveness and continuous improvement) (Barata et al., 2017). Similarly, Werbach and Hunter (2012) refer to the trinity of gamification design elements: points, badges (or levels), and leader boards. 
Characterized by its multidisciplinary nature, this concept can be applied to various theoretical fields and empirical domains with applications in areas such as marketing, education, healthcare, human resources, training, environmental protection and wellbeing (Seaborn and Fels, 2015). Its popularity in various fields can be attributed not only to technological advances that enable the use of various online platforms and tracking devices, but mostly to its foreseen potential to develop motivation, engagement, behavioural changes, friendly competition and collaboration in different contexts, such as teaching, customer engagement, employee performance and social loyalty (Dichev and Dicheva, 2017).

However, it is worth mentioning the criticism that has been attributed to its multidisciplinary literature for confusing between terms (Deterding et al., 2011). Game-based learning (learning games or serious games) uses an actual game to teach knowledge and skills whilst gamification uses a few game elements. A simulation is in turn a re-creation of circumstances you could encounter in the real world that requires problem-solving and decision making. Unlike a game or a simulation, in gamification learners do not necessarily play an entire game from start to finish. Instead they take part in activities that may include video or mobile game elements such as earning points, overcoming a challenge or receiving badges for accomplishing tasks (Kapp, 2014).

In a business research context, gamification has been mainly applied to motivate users to engage with an application or service, usually by making it more 'fun' to use (Deterding, 2011). This author proposed a model based on the concept of motivational affordances (Zhang, 2008) and need satisfaction theories, in particular the self-determination theory (Deci and Ryan, 1985; Ryan and Deci, 2000; Ryan and Deci, 2002). Although other theories have been used to study gamification, such as for example the goal-setting theory (Gollwitzer and Oettingen, 2012), the self-determination theory (SDT) is to date the most-frequently used psychological theory in gamification research (Seaborn and Fels, 2015). SDT focuses on innate growth and psychological needs (including the need to feel competent, the need for autonomy and the need to feel connected to others) and circumstances required to boost the development process of those needs (Ryan and Deci, 2000). Following this theory, it is claimed that the mere fact of transferring elements from game to non-game contexts does not lead to motivational affordances. This theory argues that these elements must be necessarily situated. This situation will shape the usage, meaning, and consequential motivational affordances. In this study, the various challenges provided by the Studyka platform to participants create these situations through recreation that shape the usage, meaning and subsequent motivational affordances. 
Barata et al. (2017) give a detailed description of different uses of gamification in education such as numerical methods, biology, programming, amongst others, but they do not mention entrepreneurship. According to Barata et al. (2017), gamification of education is a recent subject, and research shows promising results. Research has suggested that gamification may increase students' activity (Denny, 2013) and performance (Domínguez, Saenz-de Navarrete, et al., 2013), but there is still a lack of empirical studies, specifically in what refers to entrepreneurship. Additionally, Nacke and Deterding (2017) suggest that there is a lack of studies that assess other behavioural outcomes beyond the typically assessed. To our knowledge, there are no other studies that investigate the impact of gamification on EI. Our research aims at shedding some light over this gap.

\section{Entrepreneurship}

Entrepreneurship is a field that always generates a lot of interest, either because people imagine that they could start their own enterprises or because they admire others that have done so. Understanding what entrepreneurship is and its associated theories is fundamental (Fiet, $2001 \mathrm{ab}$ ), but more importantly, addressing the gap between what and how it manifests and how it is trained (either in the context of private companies or Universities) becomes the important dilemma to address (Gielnik et al., 2015; Rauch and Hulsink, 2015; Sidhu et al., 2015).

First introduced in Universities curricula in the 1970s, entrepreneurship became a discipline and is taught in most Business Schools around the world under one form or the other with varying curriculums (Vesper and Gartner, 1997). Still, teaching entrepreneurship is a contentious topic, hence the gap in the market for gamified products and companies that sell the promise of entrepreneurship training (Fayolle, Verzat and Wapshott, 2016).

There has been a lot of discussion in the managerial literature regarding whether entrepreneurship is an innate set of attributes or whether it is something that can be learned or taught (Boulton and Turner, 2005; Mellor, et al. 2009; Fayolle, Verzat and Wapshott, 2016; Kamovich and Foss, 2017). Thus, some authors argue that entrepreneurial disposition increases with education (e.g., Giacomin et al., 2011; Rauch and Hulsink, 2015) whilst others state that education diminishes entrepreneurial aspiration (e.g., Laukkanen, 2000).

Whether you consider it innate or not, or a mix of both views, the truth is that this is definitely a phenomenon that has been on the rise and that has seen a significant interest from both practitioners and academics given its common associations to employability and economic growth (Baron and Shane, 2008; Koe et al., 2012). 
In educational settings, students learn more if they actually have experiences and do something instead of just hearing about it in theory in the context of a classroom, which would be typical in a traditional and old-fashioned teaching style (Kolb, 1984; Fiet, 2001ab; Kolb and Kolb, 2005). Fortunately, the Higher Education (HE) sector has evolved and the traditional oneway teacher centred approach is no longer the common practice (Fry, Ketteridge and Marshall, 2009). This is also true in a business context where training skills, particularly entrepreneurial related skills, has evolved substantially from when it first emerged (Douglas and Shepherd, 2002). It is also well documented that your learning will improve with peers' interaction in the same form as it will improve when you get to experience things and transfer the feelings of those experiments into a real context (Ryan and Deci, 2000; Hamari, 2013).

Nonetheless, entrepreneurship training is not easy, particularly because most studies are unable to establish longitudinal approaches and direct relationships between the training and entrepreneurial behaviours (Fayolle, Verzat and Wapshott, 2016; Kamovich and Foss, 2017). Consequently, research has focused on the development of EI as a proxy of entrepreneurship behaviours (Carr and Sequeira, 2007; Kautonen et al., 2009, 2015; Schwarz et al., 2009).

\section{Entrepreneurial Intentions (EI)}

Since the late 1980s, a considerable body of literature has addressed the concept of entrepreneurial intentions (EI) (Kautonen, Gelderen, and Fink, 2015). EI refer to "the intention to start a new business" (Pillis and Reardon, 2007:383), hence used as a measure associated to entrepreneurship. Studying EI using socio-cognitive frameworks has been deemed appropriate by the academic community (Zhao, Seibert, and Hills. 2005). An example is the theory of planned behaviour (TPB) which is commonly used and supported by scholars in the study of EI as it enables the understanding of the links between these intentions and behaviours (e.g., Norris and Carsrud, 1993; Krueger, Reilly, and Carsrud. 2000; Li, 2007; Engle, et al., 2010; Pihie and Bagheri, 2011; Rauch and Hulsink, 2015). According to the TPB, intentions are the single best predictor of most planned behaviour, including entrepreneurial behaviour (Krueger et al., 2000; Kolvereid and Isaksen, 2006). Intention refers to "the indication of how hard people are willing to try, of how much an effort they are planning to exert, in order to perform the behavior" (Ajzen, 1991, pp 181). This theory sees intentions as resulting from attitudes, perceived behavioural control, and subjective norms (see figure 1). Furthermore, research has also suggested new frameworks for EI based on this theory. For example, in their conceptual paper, Koe et al. (2012) propose a research framework based on Ajzen's (1991) theory of planned behavior (TPB) to study EI among millennial generation in Malaysia. Their framework 
focuses on knowledge, experience and ties as the independent variables, and on attitude, social norm, perceived behavioural control and personality traits as the mediating variables.

\section{- FIGURE 1 - ABOUT HERE}

In applying TPB to EI, Attitude toward the Behaviour (ATT) (also known as personal attraction) indicates the level to which the individual has a positive or negative evaluation on being an entrepreneur (Ozaralli and Rivenburgh, 2016). These attitudes are developed based on the beliefs regarding the consequences (intrinsic and extrinsic rewards) of the considered behaviour (Ajzen, 2005), in this case entrepreneurship or entrepreneurial behaviours. When considering entrepreneurship, these consequences are usually seen as having a positive impact on the intention to start a new venture (Choo and Wong 2006; Vanevenhoven and Liguori 2013).

In turn, Subjective Norms ( $S N$ ) relate to the opinions of others (such as peers, family, friends, etc.) with regards to the decision to engage in entrepreneurship behaviours. These opinions work as our frame of reference when making decisions (Ozaralli and Rivenburgh, 2016). Overall, research as shown a weak influence of subjective norms on intentions (Armitage and Conner 2001).

Unlike the previous concepts that relate to external perceptions or opinions, Perceived Behavioural Control (PBC) refers to the individual's own opinion, self-confidence and selfassurance on the ability to perform the considered behaviour (Ajzen, 2005). PBC is also known as self-efficacy in entrepreneurial settings and has been positively associated with entrepreneurial behaviours (Krueger et al., 2000; Liñán, 2008).

\section{Gamification and Entrepreneurship}

Very little has been done on gamification and entrepreneurship. The literature is scarce and so is the empirical evidence. Moreover, some studies still argue over the effects of gamification (Sailer et al., 2017), as well as over the effects of the development of entrepreneurship skills on EI (e.g., Bae et al., 2014). With this in mind, the purpose of this research project was to address this by investigating the impact of gamification on EI and also on all the other antecedents of this construct according to the TPB namely Attitude toward the Behaviour, Subjective Norms and Perceived Behavioural Control.

Forming entrepreneurial mind-sets demands the adoption of innovative teaching methods and content that may break with traditional approaches (Sidhu et al., 2015; Gielnik et al., 2015; Rauch and Hulsink, 2015). In line with this, games (e.g., Antonaci, et al., 2015; Fellnhofer, 
2015; Kearney et al., 2016) and gamification have been used to foster entrepreneurship (e.g., Ruiz-Alba et al., 2016; Rughinis, Rosner and Matei, 2016). The use of gamification to support the development of EI and behaviours is supported by gamification definitions which suggest that gamification attempts to engage users to influence specific behaviours (Deterding et al., 2011; Barata et al., 2017; Robson et al., 2016).

However, it is worth mentioning that more examples of research using games/serious games and simulations to develop entrepreneurship could be found in journal articles than actual experiences of gamification. This shows the lack of empirical research available on actual gamification effects and its relationship with EI. The present research tries to address this gap by providing clear evidence using a well-established framework in EI to demonstrate the impact of gamification.

As a result, both scholars and practitioners have called for further studies and investigations into the drivers, pedagogical methods and effects of entrepreneurial outcomes (Phan, Siegel and Wright, 2009; Verzat, Byrne and Fayolle, 2009; Kobia and Sikalieh, 2010; Sidhu et al., 2015), hence the focus of this study where there is an attempt to shed some light over (1) the development of gamified products and (2) the effects of that gamified context on the development of EI.

\section{Research Framework and Hypotheses}

The rationale supporting the training of EI using gamification is based on the SelfDetermination Theory principles (Deci and Ryan, 1985; Ryan and Deci, 2000; Ryan and Deci, 2002). Within the remits of this theoretical approach, adding game-like elements to learning activities will create immersion in a way similar to what happens in games (Verzat, Byrne and Fayolle, 2009; Codish and Ravid, 2015), where individuals can make their own decisions and learn inductively (Prince and Felder, 2006), thus strengthening their creativity and retention (Prince, 2004; Caponetto, Earp and Ott, 2014). This is then expected to contribute to the change in behaviours (Holman et al. 2013). Given this, and because TPB aligns with the study of EI, it also seems to be the appropriate framework to investigate gamification outcomes related to EI.

Overall, research has supported the use of TBP in the study of entrepreneurship and confirmed the relationships between the variables in this model (Krueger et al., 2000; Liñán, 2008; Liñán et al., 2011; Veciana, Aponte and Urbano, 2005; Iakovleva, Kolvereid and Stephan, 2011; Kautonen et al., 2015; Rauch and Hulsink, 2015). As a result, the relationships between these variables are expected to be similar and actually be enhanced in a context of gamification 
given the expected behavioural/motivational changes attributed to gamification (Deterding et al., 2011; Robson et al., 2016; Barata et al., 2017; Huotari and Hamari, 2017).

Our aim is not therefore to test TPB effects as this has been extensively done in the past (Armitage \& Conner, 2001). Instead, our aim is to show that these effects are present as expected but, more importantly, that they are enhanced by the use of gamification, hence the choice of this well-established framework and the methodological choices with before and after the gamification experience analysis.

\section{Entrepreneurial intentions (EI)}

In an attempt to explore the differences between EI variables, Do Paço et al. (2011) use TPB and a questionnaire based on Liñán and Chen (2009). They concluded that TPB was an appropriate model to the development of EI in pedagogical and learning settings and emphasised the importance of entrepreneurship educational programmes to the development of skills related to entrepreneurship.

Fayolle, Gailly and Lassas-Clerc, (2006) explored the impact of entrepreneurship education programmes and demonstrated they had a strong measurable impact on students' entrepreneurial intention and a positive, but not very significant, impact on their perceived behavioural control. Iakovleva and Kolvereid (2009) explore whether the TPB (Ajzen, 1991) and the model of the entrepreneurial event (Shapero and Sokol, 1982) can be integrated into one model of entrepreneurial intentions. Their results show that the two intention models can be successfully integrated into one, where attitude, subjective norm and perceived behavioural control determine desirability-feasibility, which in turn, determines intentions. They also clarify the differences between different types of entrepreneurial intentions (acquire a business, become self-employed and to start and run a business).

Schwarz et al. (2009) found significant differences in entrepreneurial intent regarding age, gender and field of study. They showed that male students were more enthusiastic about business ownership than their female counterparts.

Engle et al. (2010) investigated TPB and found that it predicts successfully entrepreneurial intent in each of the study countries. They also found that the significant contributing model elements differ by country as does the percent of the variance explained by the model, although one model element, social norms, was a significant predictor of entrepreneurial intent in each country.

Iakovleva, Kolvereid and Stephan (2011) found that respondents from developing countries have stronger entrepreneurial intentions than those from developed countries. Moreover, the 
respondents from developing countries also score higher on the theory's antecedents of entrepreneurial intentions - attitudes, subjective norms, and perceived behavioural control than respondents from developed countries.

Heuer and Kolvereid (2014) examined the relationship between entrepreneurship education and entrepreneurial behaviour, comparing the effectiveness of frequently used entrepreneurship education teaching approaches. Results showed a strong direct relationship between participation in extensive education programmes in entrepreneurship and EI.

Soomro and Shah (2015) studied the attitudes and intentions of individuals towards entrepreneurship. They found a significant and positive correlation between entrepreneurship intention and attitudes towards entrepreneurship. A high correlation was found between entrepreneurship intentions and attitudes towards behaviour and low correlation was found between innovation and attitudes towards behaviour.

Karimi et al. (2017) explored the EI TBP model in Iran and all variables showed relationships with EI, whether these were direct or indirect relationships. They explain the differences from typical outcomes with cultural variables. Perceived contextual support and barriers indirectly related to EI through proximal PBC while apparent barriers also directly related to EI.

Given that these findings have been broadly established in the literature, it is expected that the effects portrayed by the TBP model can be, not only maintained, but also reinforced through the use of a gamified setting. This is supported by the self-determination theory principles (Deterding et al., 2011; Robson et al., 2016; Barata et al., 2017; Huotari and Hamari, 2017). Hence, the following hypothesis is proposed:

H1. Entrepreneurial intentions will be higher after the gamification experience.

\section{Attitude toward the Behaviour (ATT)}

Keong and Hirst (2010) used the TPB model to foretell innovation adoption behaviours. They were able to support all TBP relationships, particularly with regards to attitudes and subjective norms which revealed to be significant predictors of intentions, subsequently predicting innovation adoption behaviours.

Krueger, Reilly and Carsrud (2000) investigated and compared the effects of TPB and Shapero's model of the entrepreneurial event (SEE). They concluded that intentions are the single best predictor of any planned behaviour, including entrepreneurship. They also stated 
that role models will affect entrepreneurial intentions only if they change attitudes and beliefs such as perceived self-efficacy.

Souitaris, Zerbinati and Al-Laham (2007) results illustrate that entrepreneurship programmes promote some entrepreneurial attitudes and the overall entrepreneurial intention and that inspiration (a construct with an emotional element) is the programmes' most influential benefit.

Fretschner and Weber (2013) develop an "entrepreneurship education model” (EEM) based on TPB. They found support for the proposed causal link from awareness education to students' entrepreneurial attitudes derived in the EEM. They also found that PBC is not a relevant predictor of start-up intentions in an awareness setting. Most importantly they were able to demonstrate two course-induced effects on students' belief systems determining their personal attitude: the corruption effect of extrinsic motivation and a shift in locus of control.

Solesvik et al. (2013) concluded that entrepreneurship-specific education (ESE) students reported higher intensity of entrepreneurial mindset. Further, ESE students who accumulated the connection entrepreneurial alertness asset reported higher intensity of entrepreneurial mindset. ESE students were more oriented to higher entrepreneurial mindset when they had accumulated more connection entrepreneurial alertness asset. ESE students who accumulated the risk-taking propensity asset reported lower intensity of entrepreneurial mindset. ESE students were more oriented to higher entrepreneurial mindset when they perceived less risk.

Using TBP, Lapkin, Levett-Jones and Gilligan (2015) predicted health professional students' behavioural intentions with regards to medication safety and collaborative practice, determining the influence of attitudes, subjective norms, and perceived control on behavioural intentions. Their results showed strong prediction in comparison to previous studies and showed that attitude was the most significant predictor of participants' intention to collaborate with other team members to improve medication safety.

Wach and Wojciechowski (2016) confirmed the relationships between attitude towards entrepreneurship, subjective norms and perceived behavioural control and EI of students. They also discovered that the risk attitude was a determining factor, extending TPB to include risk propensity as a separate variable describing attitude towards entrepreneurship.

As these examples demonstrate, the literature tends to offer positive effects of attitudes towards behaviours; therefore, the following hypothesis is suggested:

H2. Attitude toward behaviour (ATT) will be higher after the gamification experience. 


\section{Perceived Behavioural Control (PBC)}

Following the TPB literature, PBC (or self-efficacy as it is sometimes measured) tends to exhibit a positive effect on EI (Krueger et al., 2000; Liñán, 2008). In their review of TPB, Armitage and Conner (2001) found that PBC accounted for significant amounts of variance in intention and behaviour.

Brown et al., (2003) looked at the attitudes of pharmacists regarding independent pharmacy ownership. Overall, they found a favourable attitude toward independent pharmacy ownership, strengthened by beliefs that ownership would improve their business and professional autonomy as well as enable patient loyalty. Pharmacists with a higher interest in pursuing ownership and those with advanced training certifications had significantly more favourable attitudes toward ownership than their counterparts.

In his investigation, Liñán (2008) found an effect of both subjective norms and perceived behavioural control on EI, but with a stronger effect of the later variable.

BarNir, Watson and Hutchins (2011) findings suggest that role models have a significant and positive impact on intention, that gender moderated the effects, and that self-efficacy mediated it. A moderated mediation relationship was observed such that, for women, role models had stronger influence on self-efficacy, which, in turn, influenced entrepreneurial career intention.

Ferreira et al. (2012) found that the need for achievement, self $\square$ confidence, and personal attitude had a positive effect on EI. They also concluded that subjective norms and personal attitude had an impact on perceived behavioural control.

Solesvik et al. (2012) found that students reporting higher levels of attitude toward the behaviour (i.e. enterprise) and perceived behavioural control were more likely to report the formation of entrepreneurial intentions.

Piperopoulos and Dimov (2015) results show that higher self-efficacy is associated with lower entrepreneurial intentions in the theoretically oriented courses and higher entrepreneurial intentions in the practically oriented courses.

Rauch and Hulsink (2015) supported entrepreneurship education and found that students participating in entrepreneurship education showed an increase in attitudes and perceived behavioural control. These students also shown higher entrepreneurial intentions at the end of the program. Their results also suggest that entrepreneurial intentions mediate the effect of entrepreneurship education on subsequent entrepreneurial behaviour.

Westhead and Solesvik (2016) demonstrated that entrepreneurship education (EE) students reported high intensity of intention highlighting the role of gender as a differentiating factor. 
Women were significantly less likely to report high intensity of intention; however, those citing the alertness skill were more likely to report high intensity of intention than non-EE women students. Both male EE and non-EE students citing the risk perception skill reported higher intention, whereas women EE students citing the risk perception skill reported lower intention.

As a result, gamification is expected to positively influence the effects of $\mathrm{PBC}$, hence:

H3. Perceived behavioural control (PBC) will be higher after the gamification experience.

\section{Subjective Norms (SN)}

Most of the research has shown limited or no influence of subjective norms on intentions (Armitage and Conner 2001). For example, Gelderen et al. (2008) studied the EI of business students applying the TPB model as a theoretical background. They found that the two most important variables to explain EI are entrepreneurial alertness and the importance attached to financial security (that is their attitude towards the behaviour), but they found very limited support for subjective norms.

Liñán and Chen (2009) highlight the impact of culture in TPB effects and dimensions. They support the use of the model to measure entrepreneurial intentions and demonstrate that four of the five original core-model relationships were significant. SN would exert its influence on both attitude and PBC (which in turn explain intention), but not directly on intention.

Moriano et al. (2011) studied EI across cultures using TPB with a sample of 1,074 students from Germany, India, Iran, Poland, Spain, and The Netherlands. This study revealed universal effects of attitudes and perceived behavioural control (self-efficacy) on EI, but the effects of subjective norm were influenced by culture.

Karimi et al. (2014) results supported the TPB hypothesized relationships showing that entrepreneurial role models indirectly influence EIs via the antecedents of intention. No gender differences in the relationship between PBC and EIs were found. Nonetheless, gender moderated the other relationships within the TPB. Attitude towards entrepreneurship was a weaker predictor and SN a stronger predictor of EIs for female students than for their male counterparts. PBC and attitudes towards entrepreneurship were also more strongly influenced by role models for females as opposed to male students.

Ruiz-Alba et al. (2015) found that perceived behavioural control and attitudes had an impact on the EI of university students towards entrepreneurship whilst subjective norms did not. They 
also highlight the role of gender showing that gender has a moderating effect and a positive influence for women in the relationship between SN and the PBC.

Alonso-Galicia (2015) also supported the role of gender from a different angle. Their results demonstrated that the influence of close social groups is perceived differently, i.e., the support received for academics' attitudes and perceptions of control over the development of EI is different for males and females.

This means that Subjective Norms (that is, the influence of opinions of others) would not be expected to have major changes on EI even when considered in a context of gamification, hence the hypothesis suggested:

H4. Subjective norms (SN) will not be higher after the gamification experience.

\section{Methodology}

To address the identified research gap and investigate the hypothesised relationships of TBP for EI in a gamified context, the present study adopted a mainly quantitative research strategy, using self-administered questionnaires.

In particular, a mixed experimental design with repeated measurements has been implemented with a within subject factor with two levels (moments of evaluation of the dependent variables) and a control variable (gender of respondent).

To ensure that the experience that is being analysed here could be classified as gamification, a table (based on the prior literature review) was developed that shows that most of the elements that define gamification were present in our study (see Table 1). The authors of this study worked closely with the owners and top management of the company to design the research methodology before the experiment was conducted.

\section{Variables and measurement instruments}

As shown by the studies previously mentioned, overall scholars have supported the use of SDT to explore gamification effects and the use of TPB to investigate EI and various empirical instruments are available for research replication. Liñán and Chen (2009), using TPB as the theoretical framework, developed measurement instruments for the case of EI and for other variables relevant for EI such as Attitude toward the Behaviour, Subjective Norms and Perceived Behavioural Control. These scales have shown accepted levels of psychometric properties and are adapted to the specific context of entrepreneurship, for that reason it was convenient to use them in this study. 
The questionnaire was revised by 6 academics and 5 managers of the company and a pilot test was conducted. The independent variable or treatment consists of a gamification experience organised by Studyka, the privately-owned company in charge of the online platform.

Studyka (which has been recently renamed as Agorize) is a start-up that has been specializing in open innovation challenges since 2010. Agorize helps large corporations to efficiently engage with high-value communities from all around the world such as IT profiles, start-ups and students in order to get direct access to new disruptive ideas and upcoming high profiles. Many international companies trust Agorize to implement their gamification experiences including Google, Microsoft, Bank of America, Uber, Paypal, Great Place to Work, HP, Orange, Philips, Allianz, AXA, Publicis, Unibail-Rodamco, Vinci, Engie and Ericsson. Agorize's mission is to be the missing link between companies and organizations seeking out innovative ideas, talent, partnerships and digital transformation as well as innovators from across the world who want to be identified by and provide value to organizations and businesses.

The challenges set in the online platform help participants get real-world, hands-on learning and experience while competing for the chance of winning prizes and networking opportunities using gamification. Robson et al. (2016) identified four different parties involved in gamified experiences: players, designers, spectators and observers. These authors clearly pointed that understanding different players is key to creating successful gamification experiences. In this study the designers of the experience were trained to have a full understanding of the players in order to customise the gamified experience. The gamified experience was work-related, based on real business problematics. Students were working in teams of 3 to 5 people and had one month to work on their idea before uploading their document on Studyka's platform.

The dependent variables are formed by the change produced in EI, and by other variables that have been proved to be relevant to EI such as Attitude toward the Behaviour, Subjective Norms and Perceived Behavioural Control. Finally, the gender of respondent is used as a control variable to know whether the gamification experience has a different influence in men and women.

\section{Data collection}

In this research, gamification is characterized by the trinity of gamification design elements including points, badges (or levels), and leader boards (Werbach and Hunter, 2012) (detailed in Table 1). These are also three of the four elements earlier identified by Barata et al. (2017): (1) experience points and levels, (2) challenges or quests, (3) badges-and (4) leader boards. 


\section{- TABLE 1 - ABOUT HERE}

The survey was conducted twice: before and after the gamification experience. In both cases the same questionnaire was used. Data was collected from the online platform managed by coordinators of this challenge.

The first round of the survey was conducted three days before the beginning of the challenge. The online survey was uploaded in the same platform where the challenge took place. Researchers did not have access to personal data of the participants since this was done by the owners of the platform, in particular by the coordinator of innovation challenges that had the legal permission to contact with participants according to data protection legislation in France where they operate. The second round of the survey was conducted 22 days after the challenge began.

\section{Participants}

The selection of participants was done through a non-probabilistic convenience sampling method. In the first round 540 valid responses were collected and in the second round 356 valid responses were collected. Participants agreeing to participate voluntarily introduced their email in one of the fields of the questionnaire. In total 281 could be identified and matched as valid responses having participated in the first and in the second rounds of data collection. There were 61 questionnaires that had similar emails but not exactly the same, so to gain accuracy these were discarded. Finally, 220 valid questionnaires were kept and statistically analysed to compare effects before and after the gamification experience.

The age of participants was mainly between 18 and 24 years old $(84.27 \%)$ and between 25 and 30 years old $(13.51 \%)$. Gender was almost equally distributed (52.50\% female and $47.20 \%$ male). Regarding academic background, most of them had and Undergraduate or Postgraduate degree with four $(43.60 \%)$ or more years of study at University $(25.60 \%)$. Finally, a high percentage of participants had professional experience (88.64\%).

\section{Results and Discussion}

Mixed analysis of variance (ANOVA) has been used to test the proposed hypotheses with a within-subject independent variable (gamification experience) and a between-subjects control variable (gender). The dependent variables used are EI, and Attitude toward the Behaviour, Subjective Norms and Perceived Behavioural Control. 
Firstly, it is necessary to test whether the measurement instruments utilized in this study have convergent and discriminant validity. For that purpose, a confirmatory model has been estimated through generalized structured component analysis, in which all the latent variables have been specified as reflective. Bootstrap method with 500 repetitions has been used to determine the standard error of each estimated coefficient (Hwang and Takane, 2014). Results show that the model explains $66 \%$ of the variance of all indicators $(\mathrm{FIT}=65.95 \%$; AFIT $=$ $65.77 \%)$, that the explained proportion of covariance matrix is very high $(\mathrm{GFI}=0.99 ; \mathrm{AGFI}=$ 0.99) and that the standardized root mean square residuals, an index that is a badness-of-fit statistic, is low $(\mathrm{SRMR}=0.10)$.

All the indicators show a very high standardized relationship $(>0.70)$ and significant $(\mathrm{p}<0.01)$ with their respective latent variable. This shows that these are adequate ways of measuring how latent variables are reflected. The lowest level in composite reliability is 0.88 . This indicates that the measurement instruments used in this study have internal consistency. The average variance extracted (AVE) obtained a value above 0.67 which indicates that the latent variables and the indicators are sharing a high level of variability. All above shows that the measurement instruments used for this study have convergent validity (Table 2).

\section{- TABLE 2 - ABOUT HERE}

Discriminant validity is the extent to which a measure does not correlate with other constructs from which it is supposed to differ. A way of testing it is by showing that the variance that the latent variables are sharing with their AVE indicators is higher than the square of the correlation between each pair of latent variables (Fornell and Larcker, 1981). This condition is met in all cases that were analysed in this study (Table 3). Therefore, the measurement instruments used in this study have discriminant validity.

\section{- TABLE 3 - ABOUT HERE}

Once that convergent and discriminant validity of the scales have been confirmed, four new variables were created averaging the items that are measuring each one of them for each respondent. These variables constitute the group of dependent variables that will be used to test the effect of the gamification experience.

Regarding EI, H1 proposed that EI would be higher after the gamification experience. Results show two main effects: one related to between-subjects factor (gender) and the second 
one related to within-subjects factor (gamification experience). The interaction was not significant therefore the effect of the gamification experience was similar for male and female participants. In particular, men show a higher entrepreneurial intention than women $\left(M_{\text {men }}\right.$ $=4.76$ vs $M_{\text {women }}=3.76 ; p<0.01$ ). With regards to the effects of the gamification experience, the intention of becoming an entrepreneur is higher after the gamification experience $\left(M_{\text {after }}=4.95\right.$ vs $\left.M_{\text {before }}=4.18 ; \mathrm{p}<0.01\right)$ (Tables 4 and 5). Thus, H1 receives empirical support. Regarding the assumptions of the model, residuals follow a normal distribution $(d=0.82 ; p=0.06)$ and the within and between variances are homogeneous $(F$ $=0.26 ; p=0.61)$. However, it is not the same for between-subjects variances $(F=7.59 ; p$ $<0.01$ ), although this will have a small effect over the F statistic due to the fact that groups are approximately equal (Dean and Voss, 1999:111-112; Keppel, 1991:98-99).

This is aligned with prior research that used the TBP model to measure EI (Veciana et al., 2005; Liñán et al., 2011; Kautonen et al., 2013), but more importantly it reinforces the role of gamification in this process (Ruiz-Alba et al., 2016; Rughinis, Rosner and Matei, 2016). Hence, the relationships between these variables are expected to be enhanced in a context of gamification given the expected behavioural/motivational changes attributed to gamification (Deterding et al., 2011; Robson et al., 2016; Barata et al., 2017; Huotari and Hamari, 2017). According to the literature, intentions are the single best predictor of most planned behaviour, including entrepreneurial behaviour (Krueger et al., 2000; Kolvereid and Isaksen, 2006; Soomro and Shah, 2015; Karimi et al., 2017). The fact that the participants were experiencing an actual challenge that enabled them to experience the skills and situations mimicking real contexts enabled them to feel more confident regarding entrepreneurial contexts and subsequently enhancing their EI. This supports gamification definitions which suggest that gamification attempts to engage users to influence specific behaviours (Deterding et al., 2011; Barata et al., 2017; Robson et al., 2016).

In line with the TBP model and gamification assumptions, another reason that can explain why EI is higher after the gamification experience is because the attitude towards becoming an entrepreneur (ATT) has been incremented after the gamification experience (H2). In particular, ANOVA shows two main effects. The first one is produced between-subjects as men exhibit a higher attitude towards entrepreneurship than women $\left(\mathrm{M}_{\text {men }}=5.27\right.$ vs $\mathrm{M}_{\text {women }}=4.55 ; \mathrm{p}$ $<0.01)$. The second main effect happens within-subjects and highlights that attitude towards entrepreneurship is higher after the gamification experience $\left(M_{\text {after }}=4.95\right.$ vs $M_{\text {before }}$ $=4.84 ; \mathrm{p}=0.01$ ), for that reason $\mathrm{H} 2$ receives empirical support. The interaction between the factors was not significant therefore the effect of the gamification experience is produced in a 
similar way for men and women (Tables 4 and 5). In this case, residuals follow a normal distribution $(\mathrm{d}=0.78 ; \mathrm{p}=0.89)$ and within-subject variances $(\mathrm{F}=0.00 ; \mathrm{p}=0.99)$ and betweensubjects variances $(F=0.13 ; p=0.72)$ are homogeneous.

ATT refers to the evaluation on being an entrepreneur (Ozaralli and Rivenburgh, 2016) and has been considered in the literature as a significant predictor of intentions (Keong and Hirst, 2010; Lapkin, Levett-Jones and Gilligan, 2015; Wach and Wojciechowski, 2016). In line with this, the findings of the present research suggest that once participants experience actual situations through gamification in which to develop their entrepreneurial skills, their ATT also improves. This can be said to be a consequence of the actual process which includes rewards as the challenges are being completed. The more challenges you complete, the more badges you earn, the better your ranking is and subsequently your attitude towards the actual behavior (being or becoming an entrepreneur) will also change accordingly as you will feel confident you will be able to engage in those activities and use those skills in the future (which is reflected in PBC explained next).

Another reason that could justify that EI results are higher after the gamification experience is that perceived behavioural control (PBC) is also higher (H3). PBC refers to the individual's own opinion, self-confidence and self-assurance on the ability to perform the considered behaviour (Ajzen, 2005) and has been positively associated with entrepreneurial behaviours (Krueger et al., 2000; Liñán, 2008; Brown et al., 2003; Ferreira et al., 2012). The results in the present study show once again two main effects, although interaction is not significant. There is an effect of gender with men exhibiting a higher level of PBC than women $\left(M_{m e n}=4.14\right.$ vs $\left.\mathrm{M}_{\text {women }}=3.58 ; \mathrm{p}<0.01\right)$. Secondly, $\mathrm{PBC}$ is higher after the gamification experience ( $M_{\text {after }}=3.97$ vs $M_{\text {before }}=3.73$ ). This allows the support of H3 (Tables 4 and 5). The assumptions of ANOVA are met due to the fact that residuals follow a normal distribution ( $d$ $=0.81 ; \mathrm{p}=0.33)$ and variances within and between-subjects are respectively homogeneous $(\mathrm{F}$ $=0.05 ; \mathrm{p}=0.83$, and $\mathrm{F}=0.63 ; \mathrm{p}=0.43)$.

\section{- TABLE 4 - ABOUT HERE}

\section{- TABLE 5 - ABOUT HERE}

This aligns with the gamification literature that argued the positive effects of this process and with Self-Determination Theory principles (Deci and Ryan, 1985; Ryan and Deci, 2000; Ryan and Deci, 2002) which argues that adding game-like elements to learning activities creates 
an immersion where individuals can: (1) make their own decisions and learn inductively (Prince and Felder, 2006), (2) strengthen their creativity and retention (Prince, 2004; Caponetto et al. 2014) and (3) change/adjust behaviours (Holman et al. 2013).

Finally, H4 proposed that subjective norms were not expected to be different after the gamification experience due to the fact that this does not depend on the individual but on his/her the environment. SN are related to the opinions of others (such as peers, family, friends, etc.) with regards to the decision to engage in entrepreneurship behaviours (Ozaralli and Rivenburgh, 2016) and research has generally shown a feeble influence of SN on intentions (Armitage and Conner, 2001; Gelderen et al., 2008; Moriano et al., 2011; Ruiz-Alba et al., 2015).

Results are in line with the literature and the H4 suggested that a main effect can only be observed due to the gender of the subject $\left(M_{\text {men }}=5.35\right.$ vs $\left.M_{\text {women }}=4.87 ; p<0.01\right)$. However, the main effect based on gamification experience was not significant $(F=0.15 ; p$ $=0.70)$ and the interaction was also not significant $(F=0.13 ; p=0.72)$. Based on what has been here exposed, it can be concluded that $\mathrm{H} 4$ receives empirical support (Tables 4 and 5). In this occasion, variances within and between-subjects are respectively homogeneous $(\mathrm{F}=0.11 ; \mathrm{p}$ $=0.74$ and $F=0.1 .59 ; p=0.21$,$) , but residuals do not follow a normal distribution (d=0.84$; $p<0.01)$. Nevertheless, the breach of this assumption will have a weak impact on the F statistic due to the high number of experimental units of each (Keppel, 1991:97).

\section{Conclusions}

Gamification and EI open interesting avenues of research due to the dearth research on the field. Calling for a combination of different research areas and expertise knowledge, this first empirical paper about the impact of gamification on EI can help researchers and practitioners with regards to the impact of gamification on intentions and behaviour in general and in particular in the context of entrepreneurial intentions.

Main findings of this investigation suggest an impact of ATT and PBC on EI in line with the literature (Veciana et al., 2005; Liñán et al., 2011; Kautonen et al., 2013; Ruiz-Alba et al., 2016; Rughinis, Rosner and Matei, 2016). Furthermore, these effects are enhanced through gamification as expected based on the self-determination theory principles (Deterding et al., 2011; Robson et al., 2016; Barata et al., 2017; Huotari and Hamari, 2017). Not only do these results support existing theory but also bridge the gap between EI and gamification, combining both fields of research and highlighting the benefits of using gamification when attempting to change behaviours in particular towards entrepreneurship. 
Managerial implications of these findings are related to the justification of investments made by both the buyer and the supplier of the gamified experiences. Although technological advances have promoted and enabled the development of this field, $R \& D$ in this context is still an expensive ordeal so companies need to carefully consider whether to buy or make their own games to train or influence the behaviours of their employees and customers. Our experience suggests that most companies prefer to outsource these services and refer to other companies (such as Studyka/Agorize) to supply and manage the gamification experiences. The present investigation helps strengthen the case of Studyka/Agorize for the investment in gamified experiences/products, but also strengthens their confidence regarding the outcomes of their experiences.

Nonetheless, some limitations and suggestions for future research must be considered. First, this investigation has not been conducted with a longitudinal design, therefore we are unable to test the maintenance or decline of the achieved levels. Thus, this study did not explore the type of players nor their motivations which could have shed light some light into gamification, since it provides both utilitarian and hedonic benefits (Hamari, 2013; Hamari and Koivisto, 2015).

Bartle (1996) argued that players can be classified based on two dimensions: player orientation and player competitiveness. Following these dimensions, Robson et al (2016) developed a typology of players in gamified experiences: strivers, scholars, slayers, socialites. Therefore, future research should consider the extent to what gamification experiences can have differentiated impact on EI for each of the four types of players. Additionally, behaviour can be influenced by different motivations that can be present at the same time (Hamari and Koivisto, 2015). Hence, it would be interesting to investigate in future work how intrinsic and extrinsic motivations of players can have differentiated impact on EI.

It is important to acknowledge some limitations due to the experimental design used in this work. Experimental designs with intra-subject factors can threaten their internal validity due to the practice and fatigue effects, as well as the sensitization effect (Mitchell and Jolley, 2007). To minimize the effect due to the practice, the questions of the final questionnaire were randomized, while the impact of the fatigue effect can be considered negligible because this experimental design was not very demanding and consists of attractive and interesting tasks that are based on gamification. Finally, the sensitization effect has been controlled by allowing enough time between the two measurements (22 days), including more questions in the questionnaire so that the subject did not discover the objective of the investigation and including a question asking expressly for this matter. 
Finally, Robson et al. (2016) illustrated in their study some examples of failed gamification experiences, emphasizing the lack of understanding of user needs by the designers. Therefore, to plan gamification experiences that promote entrepreneurship, it would be very important to assure that designers understand very well users' needs before designing gamification mechanics. Apart from that, not only the role of designers is critical, but it is also important to assure an appropriate alignment of all the elements to the different types of players. As such, further research is called into the development mechanisms used by companies operating in this business since there seems to be currently a divide between pedagogical research and outcomes, business ventures and computing related outcomes. There is a need to bridge this gap since the future competitiveness of those businesses engaging in gamification strongly depends on their ability to understand all these three main areas, their implications, advantages and downfalls. Collaboration and a multidisciplinary outlook on this process - whether this is done through partnerships with HE institutions, developers or pedagogical experts - will be critical for future competitiveness in this business and for the future positioning of gamification as a field of research.

\section{REFERENCES}

Ajzen, I. (1991). “The Theory of Planned Behavior". Organizational Behavior and Human Decision Processes, 50, 179-211.

Ajzen, I. (2005). Attitudes, personality and behavior (2nd ed.). England: Open University Press (McGraw-Hill).

Alonso-Galicia, P., Fernández-Pérez, V., Rodríguez-Ariza, L., and FuentesFuentes, M., (2015). "Entrepreneurial cognitions in academia: exploring gender differences". Journal of Managerial Psychology, 30(6), 630-644.

Antonaci, A., Dagnino, F., Ott, M., Bellotti, F., Berta, R., Gloria, A., Lavagnino, E., Romero, M., Usart, M. and Mayer, I. (2015). “A gamified collaborative course in entrepreneurship: Focus on objectives and tools". Computers in Human Behavior, 51, Part B, 1276-1283.

Armitage, C. and Conner M. (2001). "Efficacy of the Theory of Planned Behaviour: A meta-analytic review". British Journal of Social Psychology, 40, 471-499. 
Armitage, C. J. and Conner, M. (2001). "Efficacy of the theory of planned behavior: a meta-analytic review". British Journal of Social Psychology, 40(4), 471-499.

Audretsch, D. B., Grilo, I., and Thurik, A. R. 2011. "Globalization, entrepreneurship, and the region". In M. Fritsch (Ed.), Handbook of research on entrepreneurship: 11-32. Cheltenham: Edward Elgar.

Bae, T. J., Qian, S., Miao, C. and Fiet, J. O. (2014). “The Relationship Between Entrepreneurship Education and Entrepreneurial Intentions: A Meta-Analytic Review". Entrepreneurship Theory and Practice, 38, 217-254.

Barata, G., Gama, S., Jorge, J. and Gonçalves, D. (2017). "Studying student differentiation in gamified education: A long-term study". Computers in Human Behavior, 71, 550-585.

BarNir, A., Watson, W. E. and Hutchins, H. M. (2011). "Mediation and Moderated Mediation in the Relationship Among Role Models, Self $\square$ Efficacy, Entrepreneurial Career Intention, and Gender". Journal of Applied Social Psychology, 41, 270-297.

Baron, R.A. and Shane, S.A. (2008). Entrepreneurship: A Process Perspective, 2Ed., Mason, $\mathrm{OH}$ : Thomson South-Western.

Bartle, R. (1996). "Hearts, Clubs, Diamonds, Spades: Players Who Suit MUDs", Journal of MUD Research 1, 1.

Boulton, C. and Turner, P. (2005). Mastering Business in Asia: Entrepreneurship. Singapore: John Wiley and Sons.

Brown C.M., Cantu R., Corbell Z. and Roberts K. (2003). “Attitudes and interests of pharmacists regarding independent pharmacy ownership". Journal of the American Pharmacists Association, 47(2), 174-80.

Caponetto, I., Earp, J., and Ott, M. (2014). “Gamification and education: A literature review". In European Conference on Games Based Learning (Vol. 1, 50). Academic Conferences International Limited.

Carr, J.C. and Sequeira, J.M. (2007). "Prior Family Business Exposure as Intergenerational Influence and Entrepreneurial Intent: A Theory of Planned Behavior Approach”. Journal of Business Research, 60, 1090-1098.

Choo, S., and Wong, M. (2006). "Entrepreneurial intention: triggers and barriers to new venture creations in Singapore". Singapore Management Review, 28(2), 47-64.

Codish, D., and Ravid, G. (2015). "Detecting playfulness in educational gamification through behavior patterns". IBM Journal of Research and Development, 59(6), 6-1.

Dean, A.M. and Voss, D. (1999). Design and Analysis of Experiments. Springer. NY. 
Deci, E. L., and Ryan, R. M. (1985), Self-determination, New Jersey: John Wiley and Sons Inc.

Denny, P. (2013). “The effect of virtual achievements on student engagement". In Proceedings of the SIGCHI conference on human factors in computing systems, CHI13, New York, NY, USA: ACM.

Deterding, S. (2015). "The lens of intrinsic skill atoms: A method for gameful design”. Human-Computer Interaction, 30(3-4), 294-335.

Deterding, S., (2011). "Situated motivational affordances of game elements: A conceptual model". In Gamification: Using game design elements in non-gaming contexts, a workshop at $\mathrm{CHI}$.

Deterding, S., Dixon, D., Khaled, R. and Nacke, L. (2011). "From game design elements to gamefulness: defining gamification”. In Proceedings of the 15th international academic MindTrek conference: Envisioning future media environments (pp. 9-15). ACM.

Dichev, C. and Dicheva, D. (2017). "Gamifying education: what is known, what is believed and what remains uncertain: a critical review". International Journal of Educational Technology in Higher Education, 14 (9), 1-36.

Do Paço, A.M.F., Ferreira, J.M., Raposo, M., Rodrigues, R.G. and Dinis, A. (2011). "Behaviors and Entrepreneurial Intention: Empirical Findings about Secondary Students". Journal of International Entrepreneurship, 9 (1), 20-38.

Domínguez, A., Saenz-de Navarrete, J., de Marcos, L., Fernandez-Sanz, L., Pages, C., and Martínez-Herraiz, J.-J. (2013). “Gamifying learning experiences: Practical implications and outcomes". Computers and Education, 63(0), 380-392.

Douglas, E. and Shepherd, D. (2002). "Self-employment as a Career Choice: Attitudes, Entrepreneurial Intentions, and Utility Maximization”. Entrepreneurship Theory and Practice, 26(3), 81-90.

Engle, R., Dimitriadi, N., Gavidia, J., Schlaegel, C., Delanoe, S., Alvarado, I., He, X., Buame, S., and Wolff, B. (2010). "Entrepreneurial intent: A twelve $\square$ country evaluation of Ajzen's model of planned behavior". International Journal of Entrepreneurial Behavior \& Research, 16(1), 35-57.

Engle, R.L., Dimitriadi, N., Gavidia, J.V., Schlaegel, C., Delanoe, S., Alvarado, I., He, X., Buame, S. and Wolff, B. (2010). "Entrepreneurial Intent: A Twelve-Country Evaluation of Ajzen's Model of Planned Behavior". International Journal of Entrepreneurial Behaviour and Research, 16(1), 35-57. 
Fayolle, A., Gailly, B. and Lassas $\square$ Clerc, N. (2006). "Assessing the impact of entrepreneurship education programmes: a new methodology". Journal of European Industrial Training, 30(9), 701-720.

Fayolle, A., Verzat, C. and Wapshott, R., (2016). "In quest of legitimacy: The theoretical and methodological foundations of entrepreneurship education research”. International Small Business Journal, 34(7), 895-904.

Fellnhofer, K. (2015). "Changing entrepreneurial intention and behaviour: a digital gamebased learning environment dedicated to entrepreneurship education". Journal for International Business and Entrepreneurship Development (JIBED), 8 (4), 378-404.

Ferreira, J., Raposo, M., Rodrigues, R., Dinis, A., and Paço, A. (2012). “A model of entrepreneurial intention: An application of the psychological and behavioral approaches". Journal of Small Business and Enterprise Development, 19(3), 424-440.

Fiet, J. (2001a). "The theoretical side of teaching Entrepreneurship". Journal of Business Venturing, 16, 1-24.

Fiet, J. (2001b). “The pedagogical side of entrepreneurship theory”. Journal of Business Venturing, 16, 101-117.

Fornell, C. and Larcker, D.F. (1981). "Evaluating structural equation models with unobservable variables and measurement error". Journal of Marketing Research, 18, 39-50.

Fretschner, M. and Weber, S., (2013). "Measuring and Understanding the Effects of Entrepreneurial Awareness Education”. Journal of Small Business Management, 51(3), 410428.

Fry, H., Ketteridge, S. and Marshall, S. (2009). A Handbook for Teaching and Learning in Higher Education Enhancing Academic Practice. Routledge: New York.

Gelderen, M., Brand, M., Praag, M., Bodewes, W., Poutsma, E. and Gils, A. (2008). "Explaining entrepreneurial intentions by means of the theory of planned behaviour". Career Development International, 13(6), .538-559.

Giacomin, O., Janssen, F., Pruett, M., Shinnar, R. S., Llopis, F. and Toney, B. (2011). "Entrepreneurial intentions, motivations and barriers: differences among American, Asian and European students". International Entrepreneurship Management Journal, 7, 219-238.

Gielnik, M., Frese, M., Kahara-kawuki, A., Katono, I. W., Kyejjusa, S., Ngoma, M., and Dlugosch, T. J. (2015). "Action and Action-Regulation in Entrepreneurship: Evaluating a Student Training for Promoting Entrepreneurship". Academy of Management Learning and Education, 14(1), 69-94. 
Gollwitzer, P. M. and Oettingen, G. (2012). "Goal pursuit". In R. M. Ryan (Ed.), The Oxford Handbook Of Human Motivation (pp. 1e47). Available at: http://dx.doi.org/10.1093/oxfordhb/9780195399820.013.0013 . Oxford, (Accessed: 18/09/2017).

Hamari, J. (2013). “Transforming Homo Economicus into Homo Ludens: A Field Experiment on Gamification in a Utilitarian Peer-To-Peer Trading Service”. Electronic Commerce Research and Applications, 12(4), 236-245.

Hamari, J. and Koivisto, J., (2015). "Why do people use gamification services?" International Journal of Information Management, 35(4), 419-431.

Hamari, J., Koivisto, J. and Sarsa, H. (2014). ”Does Gamification Work?-A Literature Review of Empirical Studies on Gamification”. System Sciences (HICSS) 2014 47th Hawaii International Conference 3025-3034.

Heuer, A. and Kolvereid, L. (2014). „Education in entrepreneurship and the Theory of Planned Behaviour". European Journal of Training and Development, 38(6), 506-523.

Holman, C., Aguilar, S. and Fishman, B. (2013). "GradeCraft: what can we learn from a game-inspired learning management system?" Third International Conference on Learning Analytics and Knowledge. 260-264. New York, NY: ACM.

Hunicke, R., LeBlanc, M. and Zubek, R. (2004). "MDA: A formal approach to game design and game research". In Proceedings of the AAAI Workshop on Challenges in Game AI, 4(1), 1722.

Huotari, K. and Hamari, J. (2012). "Defining gamification: a service marketing perspective". In Proceedings of the 16th International Academic MindTrek Conference, October 3-5, 2012, Tampere, Finland, ACM, 17-22.

Huotari, K., and Hamari, J. (2017). "A definition for gamification: Anchoring gamification in the service marketing literature". Electronic Markets, 27(1), 21-31.

Hwang, H., and Takane, Y. (2014). Generalized structured component analysis: A Component-Based Approach to Structural Equation Modeling (26). Boca Raton, FL: Chapman and Hall/CRC Press.

Iakovleva, T., \& Kolvereid, L. (2008). “An integrated model of entrepreneurial intentions”. International Journal of Business and Globalisation, 3(1), 66-80.

Iakovleva, T., Kolvereid, L., \& Stephan, U. (2011). "Entrepreneurial intentions in developing and developed countries". Education+ Training, 53(5), 353-370. 
Kamovich, U. and Foss, L. (2017). "In Search of Alignment: A Review of Impact Studies in Entrepreneurship Education," Education Research International, vol. 2017, Article ID 1450102, https://doi.org/10.1155/2017/1450102.

Kapp, K. (2014). “Gamification: Separating Fact from Fiction”. Available at: ttp://ww.w.cedmaeurope.org/newsletter\%20articles/Clomedia/Gamification\%20-\%20Separati ng\%20Fact\%20from\%20Fiction\%20(Mar\%2014).pdf. (Accessed: 18/09/2017)

Karimi, S., Biemans, H. J.A., Naderi Mahdei, K., Lans, T., Chizari, M. and Mulder, M. (2017). "Testing the relationship between personality characteristics, contextual factors and entrepreneurial intentions in a developing country". International Journal of Psychology, 52: $227-240$.

Karimi, S., Biemans, H., Lans, T., Chizari, M. and Mulder, M., (2014). "Effects of role models and gender on students' entrepreneurial intentions". European Journal of Training and Development, 38(8), 694-727.

Kautonen, T., Gelderen, M., and Fink, M. (2015). "Robustness of the theory of planned behavior in predicting entrepreneurial intentions and actions". Entrepreneurship Theory and Practice, 39(3), 655-674.

Kautonen, T., Tornikoski, E.T. and Kibler, E. (2009). ”Entrepreneurial Intentions in the Third Age: The Impact of Perceived Age Norms". Small Business Economics, published online 18 October 2009, DOI: 10.1007/s11187-009-9238-y.

Kearney A., Walsh P., Byrne D., Moizer J., Lean J., Di Ferdinando A., Miglino O., Friedrich R., Asperges R. and Thomson E. (2016). "Using Online Role-playing Games for Entrepreneurship Training", IN Rooney P. and Whitton N. Game-Based Learning and the Power of Play Exploring Evidence, Challenges and Future Directions, Cambridge Scholars Publishing 49-81.

Keong, Y. and Hirst, G. (2010).” An Empirical Integration of Goal Orientation and the Theory of Planned Behaviour: Predicting Innovation Adoption Behaviour". The International Journal of Entrepreneurship and Innovation, 11(1), 5-18.

Keppel, G. (1991). Design and analysis: A researcher's handbook. Prentice Hall. NJ.

Kobia, M. and Sikalieh, D. (2010). "Towards a Search for the Meaning of Entrepreneurship". Journal of European Industrial Training, 34(2), 110-127.

Koe, W., Sa'ari, J., Majid, I. and Ismail, K. (2012).” Determinants of Entrepreneurial Intention among Millennial Generation”. In Procedia - Social and Behavioral Sciences, 40, 197-208. 
Kolb, A.Y. and Kolb, D.A. (2005). "Learning style and learning spaces: Enhancing experimental learning in higher education". Academy of Management Learning and Education, 4(2), 193-212.

Kolb, D. (1984). Experiential learning: experience as the source of learning and development. Prentice Hall, Englewood Cliffs, NJ.

Kolvereid, L., and Isaksen, E. (2006). "New business start-up and subsequent entry into self-employment". Journal of Business Venturing, 21(6), 866-885.

Kristensson, P., Wästlund, E. and Söderlund, M. (2017). "Influencing consumers to choose environment friendly offerings: Evidence from field experiments". Journal of Business Research, 76, 89-97.

Krueger, N. F., Reilly, M. D. and Carsrud, A. L. (2000). "Competing models of entrepreneurial intentions". Journal of Business Venturing, 15(5-6), 411-432.

Krueger, N., Reilly, M., and Carsrud, A. (2000). "Competing models of entrepreneurial intentions". Journal of Business Venturing, 15(5-6), 411-432.

Lapkin S., Levett-Jones, T. and Gilligan, C. (2015). ”Using the Theory of Planned Behaviour to examine health professional students' behavioural intentions in relation to medication safety and collaborative practice". Nurse Education Today, 35(8), 935-40.

Larivière, B., Bowen, D., Andreassen, T. W., Kunz, W., Sirianni, N. J., Voss, C., and De Keyser, A. (2017). "Service Encounter 2.0": an investigation into the roles of technology, employees and customers". Journal of Business Research, 79, 238-246

Laukkanen, M. (2000). "Exploring alternative approaches in high-level entrepreneurship education: creating micromechanisms for endogenous regional growth". Entrepreneurship and Regional Development, 12(1), 25-47.

Li, W. (2007). "Ethnic entrepreneurship: studying Chinese and Indian students in the United States”. Journal of Developmental Entrepreneurship, 12, 449-466.

Liñán, F. (2008). "Skill and value perceptions: how do they affect entrepreneurial intention?" International Entrepreneurship and Management, 4, 257-272.

Liñán, F. and Chen, Y. (2009). "Development and Cross $\square$ Cultural Application of a Specific Instrument to Measure Entrepreneurial Intentions". Entrepreneurship Theory and Practice, 33, 593-617.

Liñán, F., and Chen, Y. (2009). "Development and cross-cultural application of a specific instrument to measure entrepreneurial intentions". Entrepreneurship Theory and Practice, 33(3), 593-617. 
Liñán, F., and Fayolle, A. (2015). "A systematic literature review on entrepreneurial intentions: citation, thematic analyses, and research agenda". International Entrepreneurship and Management Journal, 11(4), 907-933.

Liñán, F., Urbano, D. and Guerrero, M. (2011). "Regional variations in entrepreneurial cognitions: Start-up intentions of university students in Spain”. Entrepreneurship and Regional Development, 23(3-4).

Mačiulienè, M., and Skaržauskienè, A. (2016). "Emergence of collective intelligence in online communities". Journal of Business Research, 69(5), 1718-1724.

Markets and Markets. (2016). "Gamification market by solution (consumer driven and enterprise driven), applications (sales and marketing), deployment type (On Premises and cloud), user type (large enterprise, SMBs), industry and region - global forecast to 2020". Available at: http://www.marketsandmarkets.com/Market-Reports/gamification-market991.html. (Accessed: 14/11/2016).

Mellor, R., Coulton, G., Chick, A. Bifulco, A., Mellor, N. and Fisher, A. (2009). Entrepreneurship for Everyone, London: SAGE Publications.

Moriano, J.A., Gorgievski, M., Laguna, M., Stephan, U. and Zarafshani, K. (2011). “A Cross-cultural Approach to Understanding Entrepreneurial Intention". Journal of Career Development, 39 (2), p.162-185.

Mwasalwiba, E. (2010). "Entrepreneurship education: a review of its objectives, teaching methods, and impact indicators". Education + Training, 52(1), 20 - 47.

Nacke, L.E. and Deterding, S. (2017). "The maturing of gamification research". Computers in Human Behaviour, 71, 450-454.

Norris, J. and Carsrud, A. (1993). "Entrepreneurial intentions: Applying the theory of planned behaviour". Entrepreneurship and Regional Development, 5(4), 315-330.

Ozaralli, N. and Rivenburgh, N. (2016). "Entrepreneurial intention: antecedents to entrepreneurial behavior in the U.S.A. and Turkey". Journal of Global Entrepreneurship Research, 6:3, 1-32.

Phan, P., Siegel, S. and Wright, M. (2009). "New developments in technology management education: background issues, program initiatives and a research agenda". Academy of Management Learning and Education, 8(3), 324-336.

Pihie, Z. A., and Bagheri, A. (2011). "Malay secondary school entrepreneurial, attitude orientation and entrepreneurial self-efficacy: a descriptive study". Journal of Applied Science, 11(2), 316-322. 
Pillis, E., and Reardon, K. K. (2007). "The influence of personality traits and persuasive messages on entrepreneurial intention: a cross-cultural comparison". Career Development International, 12(4), 382-396.

Piperopoulos, P. and Dimov, D. (2015). "Burst Bubbles or Build Steam? Entrepreneurship Education, Entrepreneurial Self-Efficacy, and Entrepreneurial Intentions". Journal of Small Business Management. 53(4), 970-985.

Prince M. (2004). "Does active learning work?: A review of research". Journal of Engineering Education, 93(3), 223-231.

Prince, M. and Felder, R. (2006). "Inductive teaching and learning methods: definitions, comparisons and research bases". Journal of Engineering Education, 95(2), 123-138.

Rauch, A., and Hulsink, W. (2015). "Putting Entrepreneurship Education Where the Intention to Act Lies: An Investigation Into the Impact of Entrepreneurship Education on Entrepreneurial Behavior". Academy of Management Learning and Education, 14(2), 187-204.

Robson, K., Plangger, K., Kietzmann, J.H., McCarthy, I. and Pitt, L. (2016). “Game on: Engaging customers and employees through gamification”. Business Horizons, 59(1), 29-36.

Rughinis, R., Rosner, D., and Matei, S. (2016). "What is it like to be an entrepreneur? A framework for analysing multivoicedness of meaning in gamified learning platforms. $E$ Learning \& Softwate for Education. Issue 1, p-223-230.

Ruiz-Alba, J., Soares, A., Banoun, A. and Rodríguez-Molina, M. (2016). “Developing entrepreneurial intentions through gamification using online Business challenges". In: Edulearn 16 Conference Inspiring Learning Through Technology, 04 - 06 Jul 2016, Barcelona, Spain.

Ruiz-Alba, J., Vallespín, M., Martín-Sánchez, V. and Rodriguez-Molina, M. (2015). The moderating role of gender on entrepreneurial intentions: a TPB perspective. Intangible Capital, 11 (1), 92-117.

Ryan, R. M., and Deci, E. L. (2002). “Overview of Self- Determination Theory: An Organismic Dialectical Perspective". Handbook of Self-Determination Research, Rochester University Press, Rochester, p. 3-33.

Ryan, R.M. and Deci, E.L., (2000). "Self-determination theory and the facilitation of intrinsic motivation, social development, and well-being". American Psychologist, 55(1), 6878.

Sailer, M., Hense, J., Mayr, S. and Mandl, H. (2017). "How gamification motivates: An experimental study of the effects of specific game design elements on psychological need satisfaction". Computers in Human Behavior, 69, 371-380. 
Shapero, A. and Sokol, L. (1982). "The Social Dimensions of Entrepreneurship". Encyclopedia of Entrepreneurship, p. 72-90, Available at SSRN: https://ssrn.com/abstract=1497759

Schwarz, E., Wdowiak, M., Almer $\square$ Jarz, D. and Breitenecker, R. (2009). "The effects of attitudes and perceived environment conditions on students' entrepreneurial intent: An Austrian perspective". Education + Training, 51(4), 272-291.

Schwarz, E.J., Wdowiak, M.A., Almer-Jarz, D.A. and Breitenecker, R.J. (2009). “The Effects of Attitudes and Perceived Environment Conditions on Students' Entrepreneurial Intent: An Austrian Perspective”. Education + Training, 51(4), 272-291.

Seaborn, K., and Fels, D. I. (2015). "Gamification in theory and action: A survey". International Journal of Human-Computer Studies, 74(2), 14-31.

Sidhu, I., Johnsson, C., Singer, K. and Suoranta, M. (2015). “A Game-Based Method for Teaching Entrepreneurship". Applied Innovation Review, 1(1), 51-65.

Solesvik, M. Z., Westhead, P., Kolvereid, L., \& Matlay, H. (2012). "Student intentions to become self-employed: the Ukrainian context". Journal of Small Business and Enterprise Development, 19(3), 441-460.

Solesvik, M., Westhead, P., Matlay, H., \& Parsyak, V. (2013). "Entrepreneurial assets and mindsets: benefit from university entrepreneurship education investment". Education+ Training, 55(8/9), 748-762.

Soomro, B. and Shah, N. (2015). "Developing attitudes and intentions among potential entrepreneurs". Journal of Enterprise Information Management, 28(2), 304-322.

Souitaris, V., Zerbinati, S. and Al-Laham, A. (2007). "Do entrepreneurship programmes raise entrepreneurial intention of science and engineering students? The effect of learning, inspiration and resources". Journal of Business Venturing, 22(4), 566-591.

Storbacka, K., Brodie, R., Böhmann, T., Maglio, P. and Nenonen, S. (2016). “Actor engagement as a micro foundation for value co-creation". Journal of Business Research, 69(8), 3008-3017.

Vanevenhoven, J. and Liguori, E. (2013). “The impact of entrepreneurship education: Introducing the entrepreneurship education project". Journal of Small Business Management, 51(30), 315-328.

Veciana, J. M., Aponte, M., and Urbano, D. (2005). 'University students' attitudes towards entrepreneurship: A two countries comparison”. The International Entrepreneurship and Management Journal, 1(2), 165-182. 
Verzat, C., Byrne, J. and Fayolle, A. (2009). "Tangling with spaghetti: Pedagogical lessons from Games". Academy of Management Learning and Education, 8(3), 356-369.

Vesa, M., Hamari, J., Harviainen, J. T., and Warmelink, H. (2017). ”Computer games and organization studies”. Organization Studies, 38(2), 273-284.

Vesper, K. and Gartner, W. (1997). “Measuring progress in Entrepreneurship Education”. Journal of Business Venturing, 12, 403-421.

Wach, K. and Wojciechowski, L. (2016).” Entrepreneurial Intentions of Students in Poland in the View of Ajzen's Theory of Planned Behaviour". Entrepreneurial Business and Economics Review, 4(1):83-94.

Werbach, K., and Hunter, D. (2012). For the Win: How game thinking can revolutionize your business. Philadelphia, PA: Wharton Digital Press.

Westhead, P., \& Solesvik, M. Z. (2016). "Entrepreneurship education and entrepreneurial intention: Do female students benefit?”. International Small Business Journal, 34(8), 9791003.

Zhang, P. (2008). Technical opinion Motivational affordances: reasons for ICT design and use. Communications of the ACM, 51(11), 145-147.

Zhao, H., Seibert, S. E., and Hills, G. E. (2005). "The mediating role of self-efficacy in the development of entrepreneurial intentions”. Journal of Applied Psychology, 90(6), 1265. 